\title{
An overlooked complication of the inguinal hernia repair: Dysejaculation
}

IIlhan Ece $\mathbb{D}$, Hüseyin Yılmaz (1)

\section{ABSTRACT}

ORCID IDs of the authors:

I.E. 0000-0001-5105-0292,

H.Y. $0000-0002-3359-7670$

Cite this paper as: Ece I, Yılmaz H. An overlooked complication of the inguinal hernia repair: dysejaculation. Turk J Surg 2018; 34: 1-4.

Department of Surgery, Selcuk University, Konya, Turkey

Address for Correspondence ilhan Ece

e-mail:ilhanece@yahoo.com

Received: 19.02 .2018

Accepted: 21.02.2018

(C) Copyright 2018

by Turkish Surgical Association

Available online at

www.turkjsurg.com
The objective of this study was to investigate the rate of post-herniorrhaphy dysejaculation in the current literature. A comprehensive search of PubMed, Medline, Google Scholar, and Google databases was performed using the keywords "groin hernia and chronic pain," "inguinal hernia and chronic pain," "dysejaculation," and "ejaculatory pain." The eligible studies were evaluated in terms of ejaculatory pain and surgical technique used. Ten studies with 122 patients were eligible for the analysis. The rate of ejaculatory pain for a total of 5521 patients was found to be $2.2 \%$. The incidence of postoperative ejaculatory pain was found to be $2.1 \%$ following laparoscopic techniques and $1.1 \%$ following open repair. Open techniques were not related to the increased frequency of dysejaculation. Sufficient data could not be obtained from the studies for the ejaculatory pain, and thus, no statistical evaluation was performed. Dysejaculation is a common cause of postoperative morbidity after inguinal hernia repair. Attention to technical details of the primary operation may reduce the incidence of dysejaculation.

Keywords: Ejaculatory pain, herniorrhaphy, inguinal hernia, sexual dysfunction

\section{INTRODUCTION}

Inguinal hernia repair is one of the most widely performed surgical procedures in the world. This procedure has several complications that can result in the reduction in the quality of life and sexual activity $(1,2)$. The most commonly known long-term complications after inguinal hernia repair are recurrent hernia and chronic pain. After inguinal hernia repair, chronic pain-related sexual dysfunction may occur in $2 \%-3 \%$ of the males (3). However, dysejaculation or painful ejaculation is a neglected issue after this procedure. Post-herniotomy dysejaculation was first described by Bendavid as a painful, burning, or searing sensation during ejaculation (4). Ejaculatory pain is often located at the superficial inguinal ring that can last from a few minutes to several hours. Although dysejaculation is a rare complication of pure tissue repairs, the incidence of dysejaculation has increased with the widespread use of meshes for inguinal hernia repair. The reported rate of dysejaculation is approximately $3 \%-4 \%$ after mesh herniorrhaphy (5). Patients may even hesitate to report their sexual function, and thus, the actual incidence of dysejaculation may be even higher-than-reported. The aim of this study was to review the existing literature existing to date regarding the dysejaculation after open and laparoscopic inguinal hernia repair.

\section{METHODS}

A comprehensive search of the PubMed, Medline, Google Scholar, and Google databases was performed including the following keywords: groin hernia and chronic pain, inguinal hernia and chronic pain dysejaculation and ejaculatory pain. The search accrued data between January 2000 and December 2017. All instances of abstracts, case reports, letters to the editor, and original articles published in English language in peer-reviewed journals were evaluated. Moreover, the reference lists for relevant articles were reviewed. Repetitive articles or patient groups were excluded. Articles with insufficient information or insufficient data on patients' characteristics were also excluded. The inclusion criteria were post-herniorrhaphy ejaculatory pain in sexually active male patients. Patients with chronic inguinal pain were excluded because the pain is not related to ejaculation. Of the 17.121 articles, only 10 met the inclusion criteria; hence, a total of 122 patients were identified (Figure 1). All patients had complained about pain during or after ejaculation. Table 1 presents the following information: first author surname, year of publication, total number of sexually active patients, number of patients with dysejaculation, number of patients with postoperative sexual pain, number of patients with preoperative sexual pain, surgical technique, and median follow-up period of each study. Most of the current studies focused on chronic inguinal pain. Thus, sufficient data could not be obtained on ejaculatory pain; thus, no statistical evaluation was performed. Information regarding the rate of postoperative dysejaculation and sexual pain, surgical technique, and follow-up period was collected to assess surgical outcomes. 
Table 1. Outcomes of 10 studies related to dysejaculation following inguinal hernia repair in the literature published from January 2000 to December 2017

\begin{tabular}{|c|c|c|c|c|c|c|}
\hline Author & $\begin{array}{l}\text { Total number } \\
\text { of sexually } \\
\text { active patients* }\end{array}$ & $\begin{array}{c}\text { Number of } \\
\text { patients with } \\
\text { painful ejaculation** }\end{array}$ & $\begin{array}{c}\text { Number of } \\
\text { patients with } \\
\text { postoperative } \\
\text { sexual pain** }\end{array}$ & $\begin{array}{l}\text { Number of } \\
\text { patients with } \\
\text { preoperative } \\
\text { sexual pain** }\end{array}$ & $\begin{array}{l}\text { Surgical } \\
\text { technique* }\end{array}$ & $\begin{array}{c}\text { Follow-up } \\
\text { period } \\
\text { (months) }\end{array}$ \\
\hline $\begin{array}{l}\text { Bischoff et al. } \\
\text { (3) (2012) }\end{array}$ & 1172 & $25(2.1)$ & $88(7.5)$ & - & TAPP & 39 \\
\hline $\begin{array}{l}\text { Aasvang et al. } \\
\text { (6) (2010) }\end{array}$ & 442 & $\begin{array}{l}4 \text { (1.6) Lichtenstein } \\
1 \text { (0.5) TAPP }\end{array}$ & $25(5.6)$ & $52(11.7)$ & $\begin{array}{l}244 \text { Lichtenstein } \\
198 \text { TAPP }\end{array}$ & 6 \\
\hline $\begin{array}{l}\text { Aasvang et al. } \\
\text { (5) (2006) }\end{array}$ & 1015 & $41(4.0)$ & $68(6.7)$ & - & NA & \\
\hline $\begin{array}{l}\text { Tolver et al. } \\
\text { (7) (2015) }\end{array}$ & 113 & $1(0.9)$ & $11(9.7)$ & 29 (25.6) & TAPP & 6 \\
\hline $\begin{array}{l}\text { Nienhuijs et al. } \\
\text { (8) (2007) }\end{array}$ & 166 & $\begin{array}{c}1 \text { (0.6) Lichtenstein } \\
\text { O Kugel }\end{array}$ & - & - & $\begin{array}{l}84 \text { Lichtenstein } \\
82 \text { Kugel }\end{array}$ & 3 \\
\hline $\begin{array}{l}\text { Negro et al. } \\
\text { (9) (2011) }\end{array}$ & 520 & $1(0.2)$ & - & - & Lichtenstein & 12 \\
\hline $\begin{array}{l}\text { Schouten et al. } \\
\text { (10) (2012) }\end{array}$ & 386 & $3(0.7)$ & $35(9.0)$ & $82(21.2)$ & TEP & 27 \\
\hline $\begin{array}{l}\text { Andresen et al. } \\
\text { (11) (2017) }\end{array}$ & 259 & $\begin{array}{c}3 \text { (2.3) Onstep } \\
4 \text { (3.1) Lichtenstein }\end{array}$ & $\begin{array}{c}17 \text { (6.5) Onstep } \\
30(11.5) \text { Lichtenstein }\end{array}$ & - & $\begin{array}{c}130 \text { Onstep } \\
129 \text { Lichtenstein }\end{array}$ & 6 \\
\hline $\begin{array}{l}\text { Burgmans et al. } \\
\text { (12) (2015) }\end{array}$ & 429 & 7 (1.6) & $6(1.3)$ & $154(35.9)$ & TEP & 12 \\
\hline $\begin{array}{l}\text { Pommergaard et al. } \\
\text { (139 (2017) }\end{array}$ & 1019 & $31(3.0)$ & $115(11.2)$ & - & TAPP & 31 \\
\hline
\end{tabular}

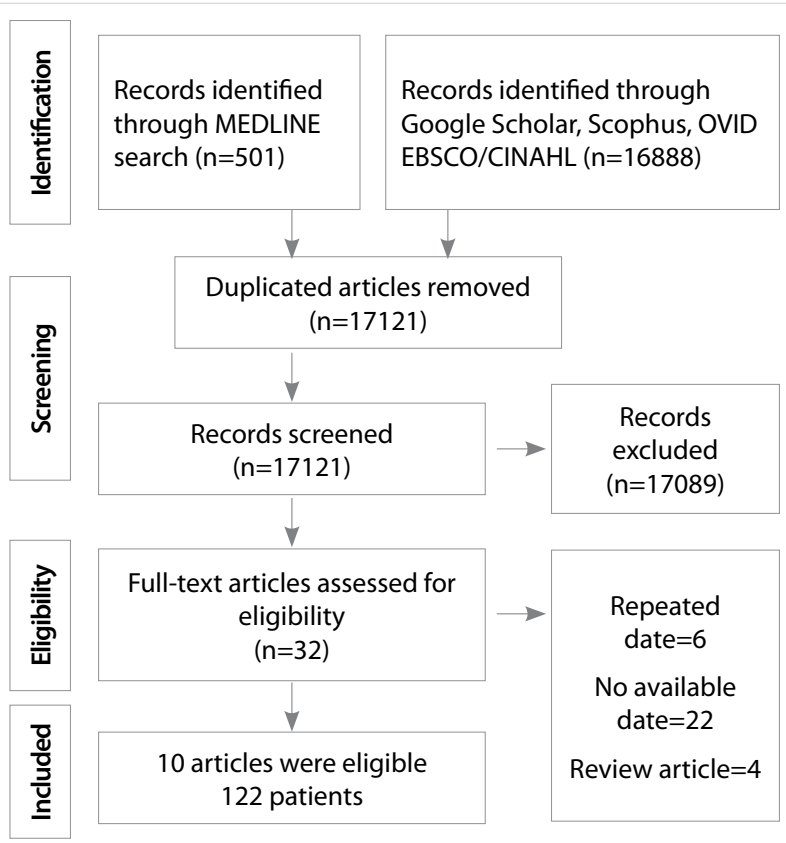

Figure 1. Flowchart of included studies

\section{RESULTS}

A total of 17,389 articles were identified from the databases. Duplicate articles and titles or keywords of the articles that did not meet the search criteria of the study were excluded. Thirtytwo articles were included for further assessment. After the review of full-text articles, 10 articles were included for the final evaluation. A total of 5521 patients who underwent inguinal hernia repair were identified, and dysejaculation was reported for 122 patients in 10 studies (3, 5-13).
A total of 3317 patients underwent laparoscopic inguinal hernia repair and 1189 patients were subjected to an open inguinal hernia repair. Transabdominal pre-peritoneal (TAPP), totally extraperitoneal repair (TEP), Lichtenstein, Kugel, and Onstep repair techniques were performed on $2502,815,977$, 82 , and 130 patients, respectively. The rate of ejaculatory pain was found to be $2.2 \%$ for a total of 5521 patients. For laparoscopically treated patients, the incidence of dysejaculation was higher with TAPP repair than with TEP repair technique (1.2\% vs. $2.4 \%)$. No dysejaculation was detected in patients who underwent Kugel operation. However, this group of patients constituted only $1.4 \%$ of the total cohort. Only 82 patients had been operated with Kugel technique, and this limitation should be considered while interpreting the study results. In contrast to our current knowledge, open techniques are not related to increased frequency of dysejaculation. The incidence of postoperative ejaculatory pain was calculated to be $2.1 \%$ (71 of 3317 ) for laparoscopic techniques and $1.1 \%$ (13 of 1189) for open repair. Eight of the 10 studies mentioned postoperative sexual pain, and the incidence of post-herniorrhaphy sexual pain was determined to be $8.2 \%$ (395 of 4835 patients). Preoperative sexual pain with an incidence of $23.1 \%$ was reported in only four of the studies comprising 317 patients in total.

\section{DISCUSSION}

Chronic inguinal pain is the well-known long-term complication of inguinal hernia repair. Moderate or severe chronic inguinal pain could cause a decreased sexual function of some patients. Dysejaculation was defined as a searing or burning sensation just prior to, during, or after ejaculation and is an ignored symptom after inguinal hernia repair. Pain is usu- 
ally experienced on the superficial ring of the inguinal canal. Recently, the incidence of dysejaculation has reportedly increased because of the routine use of meshes for inguinal herniorrhaphy. Loos et al. classified the post-herniorrhaphy pain syndromes into three groups: neuropathic pain, non-neuropathic pain, and pain possibly related to spermatic cord (14). Neuropathic pain is an activity-induced, sharp pain combined with trigger point and signs of a neurophysiological disequilibrium. It is caused by the compression of the nerves in the inguinal region with mesh or fibrosis, and half of these patients benefit from peripheral nerve blocks. Surgical removal of the mesh and transection of the nerves may be a successful way for the treatment. Incorrectly positioned deep suture on the pubic tubercle, recurrent hernia, or a missed femoral hernia could be a cause of non-neuropathic pain. An implanted mesh may also implement mechanical pressure on neighboring structures or may fold or wrinkle (meshoma), causing chronic pain (15). Spermatic cord-related pain occurs when the spermatic cord and vas deferens compress and fold with mesh and fibrosis. Sexual pain is the development of pain and hyperesthesia during erection and sexual contact. Pain is experienced on the inguinal region, suprapubic region, glans, and/or scrotal skin. Ejaculatory pain is only associated with ejaculation. The main problem is that the vas deferens becomes swollen due to the fibrosis of the mesh in the inguinal region of the patients. Intraluminal strictures and extraluminal adhesions creating a sharp, sinuous course of the vas may prevent the flow of the semen (4). Recent studies have suggested that the risk of dysejaculation can be reduced with laparoscopic techniques, especially with the non-invasive mesh fixation and use of lightweight meshes (3). Heavy patches increase the frequency of post-herniorrhaphy chronic inguinal pain as a result of ilioinguinal and iliohypogastric nerve compression with the increase of inflammation in the inguinal region (16).

The innervation of the vas deferens originates from the genitofemoral nerve of the genitalia, pelvic, and testicular plexus. Seminal vesicle and vas deferens help in ejaculation by peristaltic movements. The rhythmic contractions of the vas deferens and the tension that emerges from the semen are the main causes of pain. Direct contact of the mesh with vas deferens results in inflammation leading to pain during ejaculation (17). Verhagen et al. demonstrated that a majority of patients (67\%) experienced pain both during and after ejaculation, and $12 \%$ of patients reported only pain during ejaculation (18). The remaining $21 \%$ felt pain just after ejaculation. Pain sometimes lasted for $1 \mathrm{~min}$ after ejaculation and sometimes persisted for up to 2 days. In a great majority of patients, maximum pain was experienced on the external inguinal annulus and rarely spread to the scrotum and glans (19). In addition, the rate of patients exposed to postoperative painful ejaculation was much higher than expected. However, moderate-to-severe pain $(2.8 \%)$ causes sexual dysfunction in patients and requires medical attention (19).

A majority of studies reported that laparoscopic surgical techniques cause less sexual pain than open repair (20). However, the effects of laparoscopic procedures on dysejaculation are not clear. Only one study comparing open and laparoscopic repair reported less postoperative dysejaculation rate for laparoscopic repair (6). The analysis of 10 studies showed that the open techniques were not clearly associated with the increase in dysejaculation rate. Bischoff et al. performed a nationwide questionnaire-based study and reported that dysejaculation occurring after laparoscopic repair was present in nearly 25 (3.1\%) of 805 patients (3) and 19 (2.4\%) patients reported that the pain had impaired their sexual activity to a moderate or a severe degree. Nevertheless, Aasvang et al. (6) reported an incidence of $0.5 \%$, and Bittner et al. (21) reported $1 \%$ dysejaculation rate following TAPP repair. In a study conducted by Pommergaard et al. in 1421 sexually active patients, it was found that the use of fibrin glue and tacker during TAPP repair did not differ between the frequency, spread, and severity of ejaculatory pain (12). Aasvag et al. reported that the operations for recurrence are associated with more frequent ejaculatory pain (9.8\% vs. $3.4 \%)(5)$.

Most of the studies demonstrated that there are patients with preoperative ejaculatory pain due to inguinal hernia. The study conducted by Burgmans et al. involving 473 patients that used TEP hernia repair technique revealed a preoperative dysejaculation in 10 patients and complaints of almost eight patients disappeared within 6-12 weeks (13). However, seven new dysejaculation cases were detected post-operatively. Aasvang et al. reported a TAPP series of 442 (244 open surgery, 198 laparoscopic surgery) patients (6). There was a preoperative history of dysejaculation in six patients, whereas complaints of five patients were disappeared in the follow-up of 6 months. But five new patients experienced an ejaculatory pain (four open vs. one laparoscopic).

\section{DIAGNOSIS}

The primary diagnostic tool for dysejaculation is a carefully obtained patient history. Physical examination is normal in a majority of patients (22). Pain is always localized to the inguinal region and radiates from the deep to the superficial region. The decrease of libido and erectile function due to pain is not uncommon. Aasvang et al reported that pressure-pain detection and tolerance thresholds were significantly lower in the dysejaculatory patients and all patients mentioned their maximum pain on the external inguinal annulus. (19). Although magnetic resonance examination may show spermatic cord pathology, cord edema, and increased spermatic cord caliber (23), there was no radiographic difference between chronic inguinal pain and dysejaculatory patients.

\section{TREATMENT}

Despite the lack of adequate data in literature, it is appropriate to initiate medical treatment similar to the peripheral neuropathies. In the first step, tricyclic antidepressants and serotonin reuptake inhibitors could be preferred. Gabapentin and pregabalin may be subsequently added to the treatment. Opioids of the tramadol or oxycodone may be useful when the pain cannot be controlled (24). Surgical treatment is often suggested for moderate-to-severe ejaculatory pain syndrome that cannot be controlled by medical treatment. On the basis of surgical treatment for neuropathic pain, it is a preferred method to surgically remove the twisted mesh in the shrinking wound bed and decompressing the vas deferens (25). A strangulated vas deferens and dilation of the cord blood vessels could be seen in the inguinal area (26). Routine removal of the ilioinguinal and iliohypogastric nerves and genitofemoral nerves during this procedure is recommended to prevent neuropathic pain that may occur after the procedure (16). 


\section{CONCLUSION}

Dysejaculation is a common complication after inguinal hernia repair. Generally, moderate-to-severe pain scores decrease the quality of life and impair the sexual functions in the patients. The rate of dysejaculation is not seemingly associated with the type of surgery. Surgical technique, type of implanted meshes, and mesh fixation materials could be effective for the development of post-herniorrhaphy dysejaculation.

Peer-review: Externally peer-reviewed.

Author Contributions: Concept - I.E.; Design - I.E.; Supervision - İ.E., H.Y.; Resources - I.E.; Materials - I.E.; Data Collection and/or Processing I.E.; Analysis and/or Interpretation - I.E.; Literature Search -I.E. ; Writing Manuscript - I.E.; Critical Review - I.E., H.Y.

Conflict of Interest: No conflict of interest was declared by the authors.

Financial Disclosure: The authors declared that this study has received no financial support.

\section{REFERENCES}

1. Jenkins JT, O'Dwyer PJ. Inguinal hernias. BMJ 2008; 336: 269-272. [CrossRef]

2. Werner MU. Management of persistent postsurgical inguinal pain. Langenbecks Arch Surg 2014; 399: 559-569. [CrossRef]

3. Bischoff JM, Linderoth G, Aasvang EK, Werner MU, Kehlet H. Dysejaculation after laparoscopic inguinal herniorrhaphy: a nationwide questionnaire study. Surg Endosc 2012; 26: 979-983. [CrossRef]

4. Bendavid R. Dysejaculation an unusual complication of inguinal herniorraphy. Post Grad Gen Surg 1992; 4: 139-141.

5. Aasvang EK, Møhl B, Bay-Nielsen M, Kehlet H. Pain related sexual dysfunction after inguinal herniorrhaphy. Pain 2006; 122: 258263. [CrossRef]

6. Aasvang EK, Gmaehle E, Hansen JB, Gmaehle B, Forman JL, Schwarz J, et al. Predictive risk factors for persistent postherniotomy pain. Anesthesiology 2010; 112: 957-969. [CrossRef]

7. Tolver MA, Rosenberg J. Pain during sexual activity before and after laparoscopic inguinal hernia repair. Surg Endosc 2015; 29: 3722-3725. [CrossRef]

8. Nienhuijs S, Staal E, Keemers-Gels M, Rosman C, Strobbe L. Pain after open preperitoneal repair versus Lichtenstein repair: a randomized trial. World J Surg 2007; 31: 1751-7; discussion 17581759.

9. Negro P, Basile F, Brescia A, Buonanno GM, Campanelli G, Canonico $S$, et al. Open tension-free Lichtenstein repair of inguinal hernia: use of fibrin glue versus sutures for mesh fixation. Hernia 2011; 15: 7-14. [CrossRef]

10. Schouten N, van Dalen T, Smakman N, Clevers GJ, Davids PH, Verleisdonk EJ, et al. Impairment of sexual activity before and after endoscopic totally extraperitoneal (TEP) hernia repair. Surg Endosc 2012; 26: 230-324. [CrossRef]
11. Andresen K, Burcharth J, Fonnes S, Hupfeld L, Rothman JP, Deigaard $S$, et al. Sexual dysfunction after inguinal hernia repair with the Onstep versus Lichtenstein technique: A randomized clinical trial. Surgery 2017; 161: 1690-1695. [CrossRef]

12. Pommergaard HC, Burcharth J, Andresen K, Fenger AQ, Rosenberg J. No difference in sexual dysfunction after transabdominal preperitoneal (TAPP) approach for inguinal hernia with fibrin sealant or tacks for mesh fixation. Surg Endosc 2017; 31: 661-666. [CrossRef]

13. Burgmans JP, Schouten N, Clevers GJ, Verleisdonk EJ, Davids PH, Voorbrood CE, et al. Pain after totally extraperitoneal (TEP) hernia repair might fade out within a year. Hernia 2015; 19: 579-585. [CrossRef]

14. Loos MJ, Roumen RM, Scheltinga MR. Classifying post-herniorrhaphy pain syndromes following elective inguinal hernia repair. World J Surg 2007; 31: 1760-1765; discussion 1766-1767.

15. Amid P. Radiologic images of meshoma. Arch Surg 2004; 139: 1297-1298. [CrossRef]

16. Aasvang EK, Kehlet H. Postherniotomy dysejaculation: successful treatment with mesh removal and nerve transection. Hernia 2008; 12: 645-647. [CrossRef]

17. Uzzo RG, Lemack GE, Morrissey KP, Goldstein M. The effects of mesh bioprosthesis on the spermatic cord structures: a preliminary report in a canine model. J Urol 1999; 161: 1344-1349. [CrossRef]

18. Verhagen T, Loos MJ, Scheltinga MR, Roumen RM. Surgery for chronic inguinodynia following routine herniorrhaphy: beneficial effects on dysejaculation. Herni 2016; 20: 63-68. [CrossRef]

19. Aasvang EK, Møhl B, Kehlet H. Ejaculatory pain: a specific postherniotomy pain syndrome? Anesthesiology 2007; 107: 298-304. [CrossRef]

20. Schmedt CG, Sauerland S, Bittner R. Comparison of endoscopic procedures vs Lichtenstein and other open mesh techniques for inguinal hernia repair: a meta-analysis of randomized controlled trials. Surg Endosc 2005;19: 188-199. [CrossRef]

21. Bittner R, Gmahle E, Gmahle B, Schwarz J, Aasvang E, Kehlet H. Lightweight mesh and noninvasive fixation: an effective concept for prevention of chronic pain with laparoscopic hernia repair (TAPP). Surg Endosc 2010; 24: 2958-2964. [CrossRef]

22. lakovlev V, Koch A, Petersen K, Morrison J, Grischkan D, Oprea V, et al. A Pathology of Mesh and Time: Dysejaculation, Sexual Pain, and Orchialgia Resulting From Polypropylene Mesh Erosion Into the Spermatic Cord. Ann Surg 2018; 267: 569-575.

23. Aasvang EK, Jensen KE, Fiirgaard B, Kehlet H. MRI and pathology in persistent postherniotomy pain. J Am Coll Surg 2009; 208: 1023-1028; discussion 1028-1029. [CrossRef]

24. Finnerup NB, Otto M, McQuay HJ, Jensen TS, Sindrup SH. Algorithm for neuropathic pain treatment: an evidence based proposal. Pain 2005; 118: 289-305. [CrossRef]

25. Amid PK. Causes, prevention, and surgical treatment of postherniorrhaphy neuropathic inguinodynia: triple neurectomy with proximal end implantation. Hernia 2004; 8: 343-349. [CrossRef]

26. Aasvang EK, Kehlet $\mathrm{H}$. The effect of mesh removal and selective neurectomy on persistent postherniotomy pain. Ann Surg 2009; 249: 327-334. [CrossRef] 